\title{
Perspectives of a Rural Music Educator: A Narrative Journey through 'Sense of Place'
}

\author{
Janet Spring \\ University of Toronto
}

\begin{abstract}
There is a scarcity of research in contemporary rural studies in Canada, particularly pertaining to education. Discrepancies exist in definitions of rural and rurality. What is the meaning of rural, and how do educators define their teaching praxes? This study explores how one music teacher negotiates her role identity in a rural setting through the conceptual framework of sense of place, and how 'place' influences her education praxis. Grounded in the narrative methodological perspectives of Connelly and Clandinin (2006), this study investigates the lived experiences of one educator from a place-based lens. Findings indicate that a place-based curriculum may highlight positive aspects of rural areas, address shortcomings, and encourage rural youth to return to their rural roots.
\end{abstract}

Key Words: rural, narrative, story, place, sense of place, place-based education, critical pedagogy of place

As I look out my living room window, I see the combine driving through the rows and rows of golden wheat. For the past week, wheat heads have been bending ever so slightly as a reminder that it is time for the crop to be harvested and stored away in the grain bins until it is picked up to be processed for human consumption. Our family has been waiting for this day. Harvest is a very busy time on the farm. As the combine cuts down the wheat, the grain is loaded on the go.... a hectic place, for the crops must be harvested before the weather closes in. To me, my place and space is full of activity, yet spacious. Through every window in my home and at my school I see some indication that I live in the country, whether it be fields of crops, large farm machinery traveling down the road, or the big yellow school bus stopping at the end of each family's lane to pick the children up and deliver them to the rural school where I teach music, as I have done for the past 30 years.

I enjoy my rural 'place' with its strong community ties that make me feel safe and valued. The children I teach are my neighbour's children and the children of the parents I once taught. We know mostly everyone in the area and the history of the families. Yet the rural landscape is slowly changing. Our family farm that once was a hundred acres has expanded ten-fold. As I drive to school, I pass newly built subdivisions and notice the newcomers in the area. My 'place' is gradually expanding, and so is the essence of my place.

\section{What is Place?}

I have lived in two contrasting 'places' in my life, in an urban place growing up and then in a rural place, where I have lived throughout my music education career. Although I still maintain some attachment to the urban space of my early years, my music teaching career and immediate family have grounded me in my rural area. 'Place' therefore plays a very important part in my life, as it may for many others, for while my personal space holds sentimental value, my rural setting aligns me with family, friends and my community. A sense of place therefore incorporates not only the geographical setting, but also the impact of historical, social, and cultural influences on people's lives, as well as the ensuing relationships they develop within their communities. Wyly (2008) describes place as "invested with meaning, history and symbolism by various individuals and groups" (p. 2), which develops traditionally over a long period of time. Gieryn (2000) further explains that place "is filled up by people, practices, objects, and representations" (p. 465). According to Agnew, place represents "the local structure of feeling" (as cited in Wyly, 2008, p. 13). This condition of feeling may represent the sensitivities of a community of people, whether in a rural area, an indigenous community, a community that bonds together in an inner-city urban setting, or a small community of people coming together socially for a special purpose or function, no matter where they are located. Wyly (2008) clarifies further, "not surprisingly, the local conception of place is closely associated with ideas of community" (p. 13). Community however, may be grounded in a certain geographical space, or could be undefined in infinite space, such as an online chat group that comes together for a 'local structure of feeling' in boundless space. Community is also a term that is utilized particularly when related to rural areas, and may be inclusive or exclusive (Jentsch \& Shucksmith, 2004; Leyshon, 2008; Leyshon \& Bull, 2008, 2011). 
Utilizing a phenomenological perspective, Stefanovic (1998) critiques place stating, understanding and 'knowing' place is a qualitative experience that "extends beyond the objective boundaries of geometrical space" (p. 32) where humans are "immersed in the environment, interpreting, intuiting, sensing, responding emotionally and intellectually, and meaningfully assigning signification in a complexity of ways" ( $p$. 32 - 33). She qualifies 'special places' further stating, they are "more than merely lone points of geographical interest, they may reveal something essential about human ways of being-in-the-world" (p. 33). Some people may become attached to a particular place and establish an identity with it, holding certain traditions, rituals and habits, developing a strong satisfaction and salient attachment to place.

From a sociological perspective, the work of Gieryn (2000) provides a comprehensive representation of place. He states, "Place is remarkable and what makes it is an unwindable spiral of material form and interpretive understandings and experiences" (p. 471). Epiphanic moments also occur that make a place a very personal 'space', evoking memorable experiences and emotional responses. In addition, people identify with 'place' and are classified by their locale - 'She is a Torontonian' or, 'She was born and raised in the country; she is a country girl'.

According to Gieryn (2000), place possesses "continuity, uniqueness, boundaries, purpose and function" (p.465). Place can be a "unique spot in the universe" (p. 465) which has a physical form and becomes a significant place "when it ensconces history or utopia, danger or security, identity or memory" (p. 465). A place is therefore complete when it contains a geographical "location, material form and meaningfulness" (p. 466). Consequently, people become attached to their 'place'; for it provides stability and a safe, secure environment in which they can share a sense of being connected. It encompasses a historical perspective, related to memories of past and present associations and evokes an emotional attachment (Brooks, 2011; Corbett, 2010; Gieryn, 2000; Hummon, 1997). When a person possesses a particular attachment to place, from a geographical, emotional and spiritual sense, he or she is thought to have a 'sense of place'. This feeling or emotion is one that has been nurtured over time and one that has been influenced by day-to-day lived experiences. However, places are not always pleasant. People can also feel marginalized or threatened by certain places, when those places evoke feelings of fear, distress, or trauma or unpleasant memories (Holt, 2004; Leyshon \& Bull, 2011; Panelli, 2002).

\section{Rural Perspectives}

A thorough examination of the literature on rural issues provides a perplexing conundrum. The literature is full of stereotypical beliefs, and contains inconsistent data representations and arguments that perpetuate a rural myth of being unique, (Barley \& Beesley, 2007; Cicchinelli \& Dean, 2005; Gieryn, 2000; Hardre, Sullivan \& Cresson, 2009; Ministry of Municipal Affairs and Housing, 2004), and also as being backward and unrefined (Theobald \&Wood, 2008). Nairn, Panelli and McCormack (2003) discuss the dichotomy that exists between rural and urban places, painting contrasting pictures of depravity or a utopia, and depicting 'rural' as inclusive and 'urban' as alienating - the opposite.

In Canada, the term 'rural' is defined as a statistical depiction (Statistics Canada, 2002). This presents an unclear foundation for educators and researchers who attempt to portray an accurate representation of rural life, rural education and more specifically, rural music education. Having so many definitions compounds the confusion, and presents an insipid, pale perspective of the concept of 'rural'. Consequently, the most accurate and appropriate resources for depicting rural music education practices and teacher beliefs are the teachers' stories themselves. As Howley, Theobald and Howley (2005) observe, "The rural in rural is not most significantly the boundary around it, but the meanings inherent in rural lives, wherever lived" (p. 1). Yet, even these stories are few and far between, and in terms of a Canadian perspective, limited. Teachers who live and teach in rural areas must therefore present themselves according to who they are within their geographical rural space, what and how they practice in their place, what their emotional attachment is, and how they feel about living and teaching in their space and place. In other words, what does it mean to have a "sense of place"? In addition, how might understanding and applying place-based pedagogical perspectives to music education influence the lives of rural children and the rural voice?

\section{Rural School Characteristics}

The Ministry of Agriculture and Rural Affairs (2007) reports that in the province of Ontario, there are over 300,000 rural students attending elementary and secondary schools in districts that include small towns with populations of fewer than 100,000 and rural settings with populations less than that figure. 
The Rural Ontario Municipal Association (2011) comments on the importance of rural schools stating, "Rural schools provide a focal space for community activities to take shape and linkages between community members and families to be made (p. 8). In other words, the rural school provides more than education; it is the bonding factor in a rural community. In rural literature, the term 'community' is also discussed as being an integral part of schooling (Derrett, 2003; Dixon, 2000; Gieryn, 2000) and the school is often referred to as the "heart of the community" (Woods, p. 579).

Studies related to rural schools have reported that small rural elementary and high schools have characteristics that are very favorable for students, teaching staff, parents and community members. As small schools at the end of the last decade were closing or under threat of closure in the United States, and amalgamating into larger 'super' schools, researchers and advocacy groups began to investigate the rural issue further, addressing and promoting the benefits of smaller schools (Hunt, 2009; Isbell, 2005). This literature discusses positive attributes of rural schools such as close ties between teacher and student, sustained contact throughout elementary and secondary school among teachers and students, and a strong bond connecting elementary and secondary teaching staff and students. Reported also is a closeness and a reciprocal relationship of reliance between the school and community, collaboration and partnerships amongst rural businesses and schools, and a strong sense of value to place. Music education research identifies a strong music peer support that occurs between older and younger students in rural settings, which is not necessarily characteristic of larger urban schools (Bates, 2011; Hardre et al. 2009; Barley \& Beesley, 2007).

The literature also presents negative aspects of rural teaching and rural schools. Particularly noteworthy are these factors: isolation from major centers, lack of professional development and resources for teachers, sub-standard facilities, lack of funds for extra-curricular programs, lack of privacy in and outside of school, and a feeling of inferiority when interacting in an urban social/musical milieu (Bates, 2011; Budge, 2006). Research related to rural music education also claims that music teachers are isolated from other music colleagues due to demographics, that there is a limited number of students for ensembles, and that local communities generally provide funding for instruments and other music supplies (Isbell, 2005; Hunt 2009). However music has historically played an important role in rural areas, grounding residents in their places and linking them to their community. Hudson discusses how music creates an identity and an attachment to a particular locale. He states, "Both historically and contemporarily there are strong links between music and senses of place and identities, both of people and places" (p. 626). School music programs also create an identity for a community, for according to Hudson, "making music, produce[s] places" (p. 627). Hunt (2009) comments however, "we should learn about the music teachers' roles and the role of the music programs in any given context, such as urban and rural" (p. 45).

Consequently, questions arise as to how positive and negative factors have affected actual rural music education praxes. A more in-depth approach to rural music education using a narrative methodology is thus needed to investigate and clarify the issues that positively and negatively affect rural music educators and either negate or validate the popular assumptions found in the current literature. Teachers' voices and personal perspectives are generally absent from the literature (Brook, 2011; Maltas, 2004). This study will therefore provide a narrative account of one participant's interpretation of pertinent issues in rural education and in providing music instruction to rural students.

\section{Limitations of the Research}

The teacher selected to participate in the study is known to the researcher and teaches in the same school board where the researcher is employed. I therefore have a bias, as I am researching in "my own backyard'. This allows for greater knowledge of 'insider status' of the specific context, and greater depth of conversation due to shared experiences. However care must be taken to interrogate assumptions based on past experience. The findings of the study are not intended to be generalizable to areas outside the specific research area or individual teacher experiences.

\section{Methodology}

The participant chosen for this study is representative of the few music teachers in her board, in that music teachers are not hired specifically to teach music in a school. Music is taught to curriculum expectations, only if and when there is a teacher in the school who is either qualified or demonstrates an interest in teaching the subject, and if times and scheduling permit. In other words, it is not a 'protected' subject. Yet unofficially, this participant is the 'music teacher' in the school, as well as the designated teacher librarian and preparation time teacher. A preparation time teacher provides relief time to regular classroom teachers, 
while they plan and collaborate with other teachers. In this case, the participant teaches music and other subjects through preparation time. She also offers an extra-curricular choir program during recesses, lunches and after school.

In this study, I employ narrative methodology to investigate the lived experiences of one rural educator from a place-based lens. The study is grounded in the narrative methodological perspectives of Clandinin and Connelly (1992, 1994, 1995, 1998, 1999, 2000), Connelly and Clandinin (1986, 1988, 1990, 2006), and Clandinin, Pushor and Orr (2007), with a focus on the importance of 'personal, practical knowledge' (Connelly \& Clandinin, 1986). Connelly \& Clandinin (1991) clarify this phrase stating, "it is knowledge that is constructed and reconstructed as we live out our stories and retell and relive them through processes of reflection" (p. 125). Reflecting on stories and experiences is therefore key to the qualitative process, and particularly noteworthy in understanding teachers and their processes of teaching.

It is through the compilation of stories and interview data that the lived experiences (Van Manen, 1990; Eisner, 1991; Beattie, 2009) of educators provide the opportunity to investigate the knowledge gained through professional practices, inside and outside the classroom. As data are gathered and then composed in a narrative or 'storied' form, the narrative becomes a vehicle to expore and portray rich information. Beattie (1995a, 1995b, 2000, 2001, 2009) provides a methodological framework in her concept of the importance of teachers' stories in constructing professional knowledge in teaching. In a music educator's professional and personal life, these detailed stories can illuminate and inform the "personal, professional and scholarly" (Beattie, 2009, p. 29) knowledge related to the art of teaching music, of performing music and dialoguing with others in and throughout the process. Richardson (2009) and Pereira (2009) apply Beattie's notion of the importance of stories in a music education sense as stories allow researchers to "understand the meaning of narrative ways of knowing and being, and of learning to enact them in their personal, professional and scholarly lives" (Beattie, 2009, p. 30). As I investigate the lived experiences of one rural music educator through a narrative lens, my participant and I as the researcher come to a greater understanding of the ways the arts have shaped us as human beings and how these lived experiences inform and provide further knowledge of a personal, practical, professional and scholarly nature. Utilizing narrative inquiry in a collaborative sense, we acquire a deeper knowledge of the subject through informal dialogue, open-ended interview sessions and reading of our stories to, "reflect, reconnect, reframe, relate and re-imagine [our] musical life experiences in the context of building [our] "personal, practical knowledge" (Connelly \& Clandinin, 1986, p. 293) - in essence, "coming to know what [we] know" (Richardson, 2006, p. 79). In these circumstances, the researcher also becomes a co-participant and is no longer a mere scribe, but rather a contributor in 'living out the stories' through a mutual relationship with the participant, in which knowledge is shared and built upon for greater understanding.

\section{Data Collection}

Interviews were my main source of data gathering and occurred throughout a four-month period. Interviews followed an open-ended procedure, where the participant was asked to provide a background of her teaching praxis and how she came to teach in a rural school. All subsequent interview sessions were completely open-ended and initiated by informal unrestricted questions to springboard the conversations. Ten questions were used throughout the seven interviews that focused on the definition of rural, community, the role of space and place in her music education praxis, the issues of living and teaching in a rural community, the role of the music educator and community she teaches in, and next steps to inform rural music education practitioners and policy makers in general. Cohen, Manion and Morrison (2000) discuss the relevance of this interview format stating, "Questions emerge from the immediate context and [are] asked in the natural course of things; there is no predetermination of question topics or wording" (p. 271). Cohen et al. remark that this type of interview "increases the salience and relevance of questions; interviews are built on and emerge from observations" (p. 271). They also caution, however, that the information collected may vary from participant to participant. Nevertheless, this unstructured interview format provided rich data throughout the numerous sessions. The interviews took place in a relaxed atmosphere in a location chosen by the participant. Interviews were audio taped and transcribed, then verified for accuracy by the participant. Further meetings occurred to discuss any questions or comments that emerged during the interviews to clarify and add to the data already acquired.

Journaling by the researcher and participant also occurred via email throughout the data-gathering period. After the participant reviewed the interview transcripts, she added short narratives to further explain points that were raised during the interviews. Issues raised in the journal narratives were discussed 
later at the interview sessions. Clandinin and Connelly (1994) relate that journals are "a powerful way for individuals to give accounts of their experience (p. 421)." as well as "another method of creating field texts" (p. 421).. The authors remark that educators' journals of thoughts and experiences "weave together their accounts of the private and the professional, capturing fragments of experience in attempts to sort themselves out" (p. 421). The researcher re-storied the data gathered from the journals and the participant verified the resulting narrative stories for accuracy.

\section{Findings}

\section{Rural Definitions}

The following findings are based on data gathered throughout the interview process and the participant's narrative stories. The participant teaches in a rural hamlet, where the school is the only building in the area. Consequently, she defines 'rural' in terms of the 'lack of', where there is an absence of transportation, resources, proper facilities and particularly, traditional 'places' that define a community. She remarked,

I would define rural by the "lack of" or what is not there. I used to find it really difficult teaching the community portion of the grade 1 social science curriculum because what's in your community? Well there's nothing in the community! And I don't think the curriculum addresses that very well. There is no bank, there is a corner store, no post office per se, no grocery store, no fire department... so it's from what's not there, rather than what's there! There are no sidewalks, and again the grade 1 curriculum, which asks, what type of house do you live in? There are no apartment buildings! The kids live in single-family dwellings. The curriculum would have the kids draw a picture of [their] community. It was usually one long concession road and one tiny house and a then a whole blank canvas because there was nothing there...Most of them are bussed, with no available transit- they must be driven everywhere. (Participant Interview, March 5 , 2012)

Corbett (2010) outlines the concern of contemporary rural schools and how they are disconnected from traditional curricula. He discusses the issues raised regarding implementation of a rural school project in Nova Scotia in which his school staff examined curriculum materials used in the classroom. He states, "Not surprisingly, there was little actual local content or recognizable local representation, and that if we were to look at the school as a large text; it was fundamentally a story about somewhere else" (p. 117). Rural schools, he suggests, should therefore "develop curriculum from community sources". In that way, flexibility in curriculum will allow rural teachers to highlight the community place instead of following a curriculum that is more urban based.

The participant also discussed the 'lack of' in rural in terms of resources and facilities. She stated

The 'lack of'... no sewers; that in our school was a huge issue because that was why the grades $7 \mathrm{~s}$ and $8 s$ ended up moving to another school to lower the school population to fit the septic capacity. Everyone's on septic. The water issue is a really big deal there. There was lead in all the water and all the piping had to be replaced so that there was only one treated line coming in, things like that you wouldn't find in a regular school, in a town school, because you would have full access to properly treated water. Being on septic is really quite different than being in town.... At present, our school is slated to close in the future... For now the new push to send the students from grades 4 through 6 to the small town school, where they sent the grades 7 and 8 s a few years ago and make the school only Junior Kindergarten to grade 3, will keep the school only open for a few more years. But it will probably close in future, and if that happens, every single child will have to be bussed for a long distance; they don't want that!.... And the fate of the community? Really, if the school dies, the community will as well. (Participant

Interview, March 5, 2012)

In this rural area, the lack of proper facilities and resources lends support to a move to close the rural school, which is an integral part of the community, due to the fact that it is the only building that services the rural community and surrounding area. The participant believes that if the rural school closes, the viability and sustainability of the area is at stake.

The participant defines the term 'rural' through social interaction, where a rural place spawns familiarity, inclusiveness and togetherness, a safe place in which to live and teach. Students are classified as very well-behaved, inclusive of diversity in relation to race, age and gender, and parents are noted as positive and very supportive of the rural school objectives and endeavors, such as rallying to fight school closures and standing for the continuation of the music program. The rural population in the school district supports whole school music events, as the music program provides arts activities and concerts for the rural area. If there 
is talk of cutbacks that may jeopardize the viability of the school or special programs, the parent group assembles to voice concerns and to lobby for positive action.

There was one year when planning time was raised and I was scheduled to teach math for grade 3 and for other grades, to prepare for EQAO testing. I was not allowed to teach music. One school council president said that they wanted to hire someone to help me so that I could still do music, because she knew that my time was being totally used up in other subjects. The principal put a squash on that but I was thrilled that someone, not just one person, but the whole group could actually see what it was I had been doing; preparation for festival, choirs, solos, concerts, assemblies, and special presentations. They thought it was important enough that it shouldn't just be laid to waste. The principal finally acquiesced, even though to her, my music program was expendable. My schedule was changed and the principal allotted the other subjects to another staff member. (Participant interview, March 5, 2012)

\section{Functioning in a Rural Place}

The data reveal an emergent theme of adaptation which includes revising lessons and ensemble groupings to work within the small rural school community, bussing grade seven and eight students after school from the 'town' school to the rural school (so that they have the opportunity to participate in the French choir), and adapting to the physical structure of the outdated, inadequate school building. The participant is a librarian and preparation time teacher, therefore she teaches music in the library. The library is located in a small, regular classroom and the space doubles as a music room as well. Although the tiny space houses the library book collection, filing cabinets, display cases for library use, students must sit on the floor in a very small area for music class and for choir practices.

A second theme of affirmation emerged from the data, validating the positives of the rural area. The importance of affirmation of rural place and space is documented in academic literature, drawing attention to the fact that current curriculum tends to be based on urban characteristics, thus assuming aspects of urban living as being the norm, and thereby encouraging movement away from rural areas for better opportunities (Corbett, 2009). The participant remarked:

I find that I am always affirming the positives of our rural area. With the curriculum and students not fitting into the curriculum categories, you tell them what there is where they live is just as good as living somewhere else. I believe that the curriculum almost teaches the children that better opportunities are in urban areas. I can think of a really clear case where that is absolutely true. Two kids who grew up in our area...one stayed back to farm, and the other one went off to university and now is doing very well someplace else. And he is considered to be the success whereas the other one who stayed back isn't. And yet you know, it's a big, prosperous farm, but by society's views, he is not as successful as the other one. And I hear sometimes a comment, oh ya, she's moved back to the area to teach as if she is less a success than other people who maybe got a teaching job somewhere else. And for some reason that rural area entices people back who have gone to school and who have come back and decided to seek employment in that rural area or in the outskirts or in the urban areas that are close by.... But sometimes they are not considered as successful just because they want to come home to the rural area, or close to it. (Participant interview, April 2, 2012)

The attitude of discounting the significance of rural is well documented in many areas of academic literature (Brook, 2011; Corbett, 2010; Theobald \& Wood, 2010).

In terms of subsidization, the participant discussed the issues of having to make do with the outdated music, library and classroom resources that were provided, or purchase materials herself. She remarked, I spent a lot of money purchasing musical supplies that were needed, but not provided (Participant interview, March 5, 2012). She also discussed the lack of professional development opportunities available to her rural school staff and how she tried to outsource workshops to expand her knowledge and familiarity of new music materials that were available for purchase. In this way, she was subsidizing professional development opportunities that to her should have been available during the professional development days, or as inservice workshops as others subjects are, and provided by the board or the union during the instructional day. She stated, Very little PD is offered. A few years ago, a weekend workshop was offered for Orff. I went, but it was on my own time and a distance away (Participant interview, March 5, 2012). Goertz \& Duffy (as cited in Burkett, 2011) state, "The pursuit of PD is particularly problematic for teachers in rural school districts (p. 53). And when seeking PD opportunities, rural music teachers face unique challenges of time, place, and distance 
that can affect teacher attitude and, ultimately, delivery of instruction" (p. 54). The lack of professional development through collaboration with other music educators is also particularly challenging. She remarked:

Most teachers would have at least one colleague to consult for information or help, or with whom to collaborate but with music, that is not the case. I started in music just after the demise of the specialist teachers, and those people were then back in regular classrooms and were no longer involved with music at all. Now consultants have a new name and are 'Arts resource teachers' and have so many portfolios on their plate that they are spread thin and maybe do not even have a lot of expertise in all the areas of the Arts. For help with curriculum issues one consults with the Principal at least, but that is not the case with music. In most cases the principal has no music background whatsoever. (Participant personal communication, March 20, 2012)

As a result, music teachers in rural areas face issues of isolation from other music educators, from professional development opportunities, and from professional advice.

\section{Role of the Music Educator}

The music educator's role is wide and varied in the participant's rural area. She classified herself as teacher-librarian and planning time teacher, with responsibilities that may include teaching music and other subjects. However she is not identified as a 'music teacher', despite her 'volunteer', extracurricular role in preparing students for the rural music festival. She assumes the position of whole school choral conductor, French choir conductor, solo singing coach, and in her position as planning time music teacher for all students from junior kindergarten to grade three. This role extends throughout the school year. Her teaching responsibilities are directly dependent on the administration's agenda, the availability of time and resources as well as her interest in taking on extra responsibility for music, which is usually on her own time after school or during the lunch hour. She stated.

I am the music teacher, Kindergarten - 3, choral director for whole school ensemble, primary, junior choir, French choir, coordinator of music festival, solo coach, special events music teacher-assemblies, festivals, retirements". "When special funding packages come through for the Arts, I am the music purchaser-I had to purchase a new school music curriculum this past year with little assistance from anyone".
When mail comes in for the Music Department Rep, I am the music teacher, but never called the music teacher otherwise". I do music outside of my normal teaching responsibilities and through planning time because I am interested and love the subject! But it [music] always seems to be at the bottom of the 'important' list. (Participant Interview, May 12, 2012)

There seems to be little or no continuity in music education in her rural place and in other schools in the area. Thus programs vary from school to school depending on the availability of a qualified and/or interested teacher who is willing to assume the role. There seems also to be a lack of school board initiative to provide music to all students on a regular basis and a lack of place-based programs that exemplify and promote the positive aspects of the rural area in all subject areas. In her situation, she defines her music education identity as opportunistic and unstable because her position is circumstantial. As a result, the participant suggests that a place-based educational perspective would connect her rural place with the school community and the curriculum to eliminate these gaps in rural education.

\section{Moving Forward: A Pedagogy of Place}

The study of education from a place-based, placeconscious perspective is grounded in the lives of students and positioned in their surrounding environment. Sobel (2004) characterizes place-based education "as the pedagogy of community, the reintegration of the individual into her home ground and the restoration of the essential links between a person and her place" (p. ii). He also believes that it critiques location, the character of place, and the sustainability of place through a narrative story telling process. Gruenewald (2003) takes this idea one step further and poses that critical pedagogy and place-based education can be amalgamated to a critical pedagogy of place. He states, "Articulating a critical pedagogy of place is thus a response against educational reform policies and practices that disregard places and that leave assumptions about the relationship between education and the politics of economic development unexamined" (p. 3). From a political and educational perspective, rural needs are often disregarded and blanket policy issues are not relevant to rural areas (Arnold, Newman, Gaddy \& Dean, 2005; Wallin, 2008). Political decisions that call for the cancellation of special programs such as music and the closure of rural schools are often passed quickly without continued consultation. An adoption of a critical pedagogy of place may help to address these issues that are specific to local areas. 
Specifically related to rural curriculum studies, White and Reid (2008) comment, "Place conscious pedagogies open a way for all teacher education institutions to address the needs of rural schools and their communities - and indeed provide a framework for enriching the engagement of all teachers in their school communities, regardless of location" (p. 1-2). A curriculum, explicit to certain rural areas may help teachers become aware of the needs of their school community. For example, in the participant's area, one curriculum focus may be music. It fulfills an essential community need and fosters musical growth in students, and instills a sense of discipline, pride, and sense of place. Other communities may have a different focus, such as physical education, visual arts, science, or outdoor education. Nevertheless, place-based education fulfills many roles, and according to Sobel (2004), "is not simply a way to integrate the curriculum around a study of place, but a means of inspiring stewardship and an authentic renewal and revitalization of civic life" (p. iii).

Perhaps the most important aspect of place-based education is to inspire students to care for their community - the rural people, fellow students, teachers, parents, and particularly the environment on a local and global level. If students adopt a caring attitude toward their rural locale, they may attain the social habits necessary to expand their sense of caring for place further afield. It is also paramount that board personnel and educators adopt a reciprocal caring stewardship so that all directions in education, whether academic and/or social, promote a placebased framework based on concern and compassion for all. Oftentimes, as discussed by the participant and documented in the literature, curriculum objectives subliminally encourage students to leave rural areas (Theobald \& Wood, 2010; Corbett, 2010). Sobel (2004) critiques this perspective remarking, "there are often pressures for communities and regions to subordinate themselves to the dominant economic models and to devalue their local cultural identity, traditions, and history in preference to a flashily marketed homogeneity" (p. i). As a result, youth leave their rural area, with feelings of its inferiority in search of post-secondary schooling and to find employment and 'better' opportunities in urban regions. Through a place-based curriculum, these misconceptions of 'rural equals backward' (Theobald, 2005, p. 112) will be deconstructed as the students are taught the benefits of rural 'places' and the importance of supporting their local communities. And we must not underestimate the positive influences that rural school perspectives have on future attitudes. "Because of the centrality of schools in most rural communities, rural schools have the potential to function as both catalyst and role model for addressing a wide range of community needs and options for the future" (Leo-Nyquist \& Theobald, 1997; p. 3).

A place-based perspective may positively influence the direction of academic literature on rural education and supply pertinent data to guide educational policy. At present in Ontario, we rely on information that is based on census data, which offers blurred and stereotypical perspectives of rural people. Some of the statistical data could be representative of urban communities as well. Instead, the context of rural must be brought out in the literature (Coladarci, 2007; p. 2) through the lived stories of rural people that depict what it is like to live in a rural area, and what rural means to them. Only through these narrative stories, will we deconstruct the myths, and explore individual and local realities to either discount or validate these 'perceptions'. In other words, what is their rural sense of place?

Despite many positive attributes of place-based education, Nespor (2008) addresses some pertinent issues that come to light. Firstly, she argues that place-based education fails to recognize communities as constantly changing, and "continually interacting with what is outside their recognized boundaries" ( $p$. 480), even though some communities, like my rural 'village', tend to uphold local traditions and resist change. Secondly, Nespor cautions that further research into the complexities of place and sense of place needs to be completed to give place-based pedagogical theories further credibility. Usually linked to an environmental perspective, this theory must also address sociological issues and viewpoints on place. Thirdly, and most significantly, Nespor expresses concerns of place-based education to be "inattentive to racism, classism, ableism, and genderbased discrimination" (p. 489), which marginalizes minority groups. Since minority groups do exist in rural areas, their voices must be heard. Place-based education must therefore address this important issue in order to be acceptable, effective and equitable.

\section{Conclusion}

As our area rural schools and communities prepare for the upcoming Fall Fair celebrations, the elementary and high school students participate in academic and social activities pertaining to the fair. For a short period of time, classroom instructional lessons deviate from the traditional curriculum materials. Teachers integrate lessons into the school day that highlight the positives of our rural areas. Students prepare their entries of vegetables, fruits, baking, crafts and livestock for the fair competitions at home on their own time. However, after the celebrations are over, the short-lived, place-based 
approach is quickly abandoned. Yet many students and other community members continue to feel this strong attachment to place and sense of belonging or a sense of place, because of these special community events that seem to bring people together.

A year round comprehensive place-based curriculum may then be an asset for all schools, enabling positive aspects of each community to be highlighted and modeled, particularly in rural areas where the school is sometimes the only institution and/or building in the vicinity. However, further research is needed to deconstruct the ways in which rural communities can adapt to and benefit from social, political and educational changes in demographics. Further studies to explore realties in rural music education that relate to place and sense of place may also shed light on contemporary rural music education programs and the issues that surround these. The findings may inform current rural music educators and prospective teachers who teach or hope to more effectively teach in rural communities.

\section{References}

Arnold, M., Newman, J., Gaddy, B., \& Dean, C. (2005). A look at the condition of rural education research: setting a direction for further research. Journal of Research in Rural Education, 20(6), 1-25.

Bates, V. (2011). Preparing rural music teachers: reflecting on "shared visions". Journal of Music Teacher Education, 20(2), 89-98.

Barley, Z, Beesley, A. (2007). Rural school success. What can we learn? Journal of Research in Rural Education, 22(1), 1-16.

Beattie, M. (1995a). New prospects for teacher education: narrative ways of knowing teaching and teacher learning. Educational Research, 37(1), 53-70.

Beattie, M. (1995b). Constructing professional knowledge in teaching: narratives of change and development. New York, Columbia University: Teachers College Press.

Beattie, M. (2000). Narratives of professional earning: becoming a teacher and learning to teach. Journal of Educational Inquiry, 1(2), 113.

Beattie, M. (2001). The art of learning to teach: Preservice teacher narratives. Columbus, $\mathrm{OH}$ : Merrill Prentice Hall.

Beattie, M. (2009). A narrative arts-based pedagogy: connecting the personal, professional and scholarly. In M. Beattie (Ed.), The quest for meaning: narratives of teaching, learning and the arts (pp. 29-71). Rotterdam: Sense.

Beeson, E., \& Strange, M. (2000). Why rural matters: the need for every state to take action on rural education. Journal of Research in Rural Education, 16(2), 63-140.

Brook, J. (2011). Rural routes: Place-Based Education in Two Rural Canadian Communities, Unpublished Doctoral Thesis: Queens University, Kingston, ON, Canada.

Budge, K. (2006). Rural leaders, rural places: Problem, privilege, and possibility. Journal of Research in Rural Education, 21(13), 1-10.
Burkett, E. (2011). A case study of issues concerning professional development for rural instrumental music teachers. Journal of Music Teacher Education, 21(1), 51-64.

Cicchinelli, L.F., Dean, C.B. (2005), It's all about the quality of advice, guidance, and research for rural educators: A rejoinder to Howley, Theobald, and Howley. Journal of Rural Education, 20(19), 1-2.

Clandinin, D. J. (1986). Classroom practice: teachers' images in action. London: Falmer Press.

Clandinin, D. J., \& Connelly, F. M. (1991). Narrative and story in practice and research. In D. Schön (Ed.), The reflective turn: case studies in and of educational practice. New York: Teachers' College Press.

Clandinin, D. J., Connelly, F. M. (1994). Personal experience methods. In N.K. Denzin \& Y.S. Lincoln (Eds.). Collecting and interpreting qualitative materials. (pp.150178) London: Sage.

Clandinin, D. J., Connelly, F. M. (1995). Beginning teaching: stories of position and positioning in the landscape. In D.J. Clandinin \& F. J. Connelly (Eds.), Teachers' professional knowledge landscapes. New York: Teachers' College Press.

Clandinin, D. J., Connelly, F. M. (1996). Teachers' professional knowledge landscapes. Teacher stories, stories of teachers. School stories, stories of schools. Educational Researcher, 25(3), 24-30.

Clandinin, D. J., Connelly, F. M. (1998). Asking questions about telling stories. In C. Kridel (Ed.), Writing educational biography: Exploration in qualitative research (pp. 245253). New York: Garland.

Clandinin, D. J., Connelly, F. M. (2000). Narrative inquiry: Experience and story in qualitative research. San Francisco: JosseyBass. 
Clandinin, D. J., Pushor, D., Orr, A. M. (2007).Navigating sites for narrative inquiry. Journal of Teacher Education, 58 (1), 21-35.

Cohen, L., Manion, L., Morrison, K. (2000). Research Methods in Education. New York: Routledge Falmer.

Coladarci, T. (2007). Improving the yield on rural education research. Journal of Research in Rural Education, 22(3), 1-9.

Connelly, F. M., Clandinin, D. J. (1991). Narrative inquiry: storied experience. In E.C. Short (Ed.). Forms of curriculum inquiry: guidelines for the conduct of educational research (pp 121-154), Albany: State University of New York Press.

Connelly, F. M., Clandinin, D. J. (1986). On narrative method, personal philosophy and narrative unities in the story of teaching. Journal of Research in Science Teaching, 23(4), 293310 .

Connelly, F. M., \& Clandinin, D. J. (1988). Teachers as curriculum planners: Narratives of experience. Toronto: Teachers College Press.

Connelly, F. M., \& Clandinin, D. J. (1990). Stories of experience and narrative inquiry. Educational Researcher, 19(5), 2-14.

Connelly, F. M., \& Clandinin, D. J. (2006). Narrative inquiry. In J. L. Green, G. Camilli, \& P. Elmore (Eds.), Handbook of complementary methods in education research. Mahwah, NJ: Lawrence Erlbaum Associates.

Corbett, M. (2009). Rural schooling in mobile modernity: returning to the places I've been. Journal of Research in Rural Education, 24(7), $1-13$.

Corbett, M. (2010). Wharf talk, home talk, and school talk: the politics of language in a coastal community. In K. Schafft \& A. Y. Jackson (Eds.), Rural education for the twenty-first century: Identity, place, and community in a globalizing world (pp.115-131), University Park: Pennsylvania State University Press.

Derrett, R. (2003). Festivals and regional destinations: How festivals demonstrate a sense of community and place. Rural Society, 13(1), 35-53.

Dixon, J. (2000). Displacing place-identity: a discursive approach to locating self and other. British Journal of Social Psychology, 39, 27-44.

Eisner, E. (1991). The enlightened eye: Qualitative inquiry and the enhancement of educational practice. New York: MacMillan.

Gieryn, T. F. (2000). A space for place in sociology. Annual Review of Sociology, 26, 463-496.

Goertz, M., \& Duffy, M. (2003). Mapping the landscape of high-stakes testing and accountability programs. Theory Into Practice,
42, 4-11.

Gruenewald, D. (2003). The best of both worlds: a critical pedagogy of place. Educational Researcher, 32(4), 3-12.

Hardre, P., Sullivan, \& D., Crowson, H. (2009). Student characteristics and motivation in rural high schools. Journal of Research in Rural Education, 24(16), 1-19.

Holt, L. (2004). The 'voices' of children: Decentring empowering research relations, Children's Geographies, 2(1), 13-27.

Howley, C., Theobald, P., Howley, A. (2005). What rural education research is of most worth? A reply to Arnold, Newman, Gaddy, and Dean. Journal of Research in Rural Education, 20(18), 1-6.

Hudson, R. (2006). Regions and place: music, identity, and place. Progress in Human Geography, 30(5), 626-634.

Hummon, D. M. 1992. Community attachment: local sentiment and sense of place. In I. Altman, S.M. Low (Eds.), Place attachment (pp. 253-78). New York: Plenum.

Hunt, C. (2009). Perspectives on rural and urban music teaching. Journal of Music Teacher Education, 18(2), 34-47.

Isbell, D. (2005). Music education in rural areas: a few keys to success. Music Educators Journal, 92, 30-34.

Jentsch, B., \& Shucksmith, M. (2004). Young people in rural areas of Europe, Aldershot, UK: Ashgate.

Leyshon, M. (2008). The betweeness of being a rural youth: inclusive and exclusive lifestyles, Social and Cultural Geography, 9(1), 1-26.

Leyshon, M., Bull, J. The bricolage of the here: Young people's narratives of identity in the countryside. Social and Cultural Geography, 12(2), 159-222.

Leo-Nyquist, D., \& Theobald, P. (1997). Toward a pedagogy of place: finding common ground for rural researchers, teacher educators, and practitioners. Paper presented at the American Association for Education Research, Chicago.

Maltas, C. J. (2004). The rural music teacher: an investigation of the relationship between socialization factors and career satisfaction using symbolic interaction theory. Unpublished doctoral dissertation, University of Oklahoma, Norman, OK.

Ministry of Agriculture and Rural Affairs, Ontario. (2007). Strong rural communities-Ontario rural plan update 2007. Retrieved October 6, 2013 from http://www.omafra.gov.on.ca/english/rural/ruralp lan07/downloads/ruralplan07.pdf 
Ministry of Municipal Affairs and Housing (2004). Strong rural communities working together for success. Retrieved April 24, 2013 from: www.ruralplan.ontario.ca

Nairn, K., Panelli, R., McCormack, J. (2003). Destabilizing dualisms: young peoples' experiences in rural and urban environments. Childhood, 10(1), 9-42.

Nespor, J. (2008). Education and place: A review essay. Educational Theory, 58(4), 475 - 489.

Pereira, M. (2009). Beginning with myself: the power of music: a reflection, renewal and transformation. In M. Beattie (Ed.), The quest for meaning (pp. 75 -91). Rotterdam, Netherlands: Sense.

Richardson, C. (2006). Collaborative consonance: Hearing our voices while listening to the Choir. Unpublished doctoral dissertation: OISE, Toronto.

Richardson, C. (2009). Hearing my voice while listening to the choir. In M. Beattie (Ed.), The quest for meaning (pp. 233-250) Rotterdam: Sense.

Rural Ontario Municipal Association. (2011). A voice for rural and northern Ontario. Retrieved September 29, 2013, from www.roma.on.ca Statistics Canada. (2002). Definitions of rural: agriculture and rural working paper series. Retrieved September 5, 2013 from: http://www5.statcan.gc.ca/bsolc/olc-cel/olccel?catno=21-601-M2002061\&lang=eng
Sobel, D. (2004). Place-based education: connecting classrooms and communities. Barrington, MD: The Orion Society.

Stefanovic, I. L. (1998). Phenomenological encounters with place: Cavtat to square one. Journal of Environmental Psychology, 18, 31-44.

Theobald, P. (2005). Urban and rural schools: overcoming lingering obstacles. Phi Delta Kappan, 87(2), 116-122.

Theobald, P., \& Wood, K. (2010). Learning to be rural: identity lessons from history, schooling, and the U.S. corporate media. In K. A. Schafft \& A.Y Jackson (Eds.), Rural education for the twenty-first century (pp. 17-33). Pennsylvania: Pennsylvania University Press.

Van Manen, M. (1990). researching lived experience: human science for an action sensitive pedagogy. London, ON: Althouse Press.

Wallin, D. (2008). A comparative analysis of the education priorities and capacity of rural school districts. Educational Management Administration Leadership, 36, 566-587.

White, S., \& Reid, J. (2008). Placing teachers? Sustaining rural schooling through placeconsciousness in teacher education. Journal of Research in Rural Education, 23(7), 1-11.

Wyly, E. (2008). Sense of place. Urban Studies 200, Cities. Retrieved October 7, 2013 from www.geog.ubc.ca/ ewyly/u200/space.pdf

\section{About the author:}

Janet Spring has taught vocal and instrumental music in rural Ontario. As a doctoral candidate at the University of Toronto, her dissertation investigates perspectives in rural music education using collaborative narrative methodology through a conceptual framework of sense of place. 